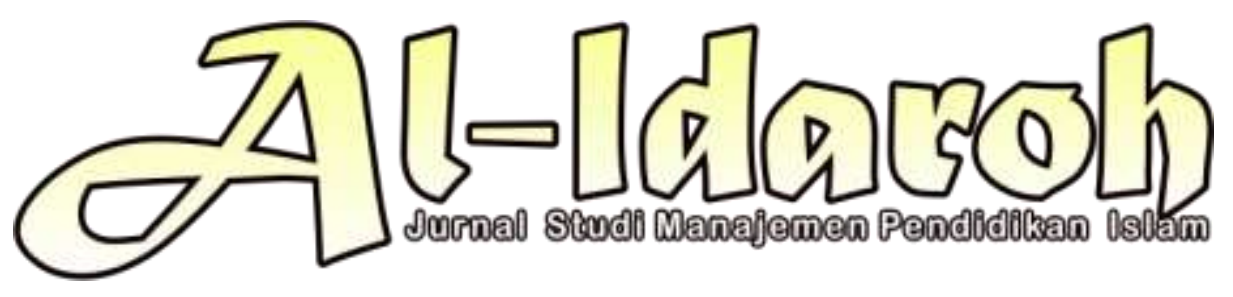

\title{
KESIAPAN GURU PAI DALAM MENGIMPLEMENTASIKAN KURIKULUM 2013 DI SMA 3 SIDOARJO DAN SMK ANTARTIKA 1 SIDOARJO
}

\author{
Karimullah \\ Institut Agama Islam Uluwiyah Mojokerto \\ Email: karimacha19@gmail.com \\ Upik Khoirul Abidin \\ Sekolah Tinggi Agama Islam Taswirul Afkar Surabaya \\ Email: tuannabi87@gmail.com
}

\begin{abstract}
Abstraks: This article is intended to capture the extent to which PAI teachers are prepared to implement the 2013 Curriculum at the SMA and SMK levels in Sidoarjo. Readiness is seen from the planning, process, and assessment. This research is a qualitative research with interview data collection technique, observation and documentation study. The main data sources in this study were PAI teachers at SMAN 3 and SMK Antarctica 1 Sidoarjo. The results showed that in general the readiness of PAI teachers in implementing the 2013 curriculum at SMAN 3 Sidoarjo and SMK Antarctica 1 Sidoarjo was good, starting from aspects of planning, implementation and assessment of learning. However, a number of obstacles were found, namely in the aspect of learning planning including the lack of understanding of PAI teachers about the 2013 curriculum; in the aspects of the implementation of learning including not being able to apply the scientific approach to the maximum; on aspects of learning assessment including the number of instruments and assessment formats that must be prepared.
\end{abstract}

Keyword: Readiness, PAI teachers, Implementation, Curriculum 2013. 


\section{Kesiapan Guru PAI dalam Mengimplementasikan Kurikulum 2013 di SMA 3 Sidoarjo dan SMK Antartika 1 Sidoarjo}

\section{A. Pendahuluan}

“Lau Laa Murabbi Maa 'Araftu Rabbi” Jika bukan kerena guruku, aku tidak dapat mengenal tuhanku". Idagium ini menggambarkan betapa pentingnya peran guru dalam proses pendidikan. Dari sekian stakeholder pendidikan, Guru memiliki pengaruh yang amat besar terhap keberhasilan implementasi kurikulum 2013. Implementasi kurikulum 2013 bertujuan untuk menghasilkan generasi masa depan yang produktif, kreatif, inovatif, efektif; melalui penguatan sikap, keterampilan, dan pengetahuan. ${ }^{1}$ Untuk itulah, maka kehadiran guru yang kompeten dan profesional merupakan sebuah keharusan sehingga mampu menerjemahkan tujuan besar kurikulum 2013 dalam proses pembelajaran secara maksimal.

Mengutip dari Iwan Wijaya bahwa guru profesional memiliki lima kriteria, 1) komitmen yang berorientasi pada siswa, 2) menguasai materi dan metode pembelajaran, 3) menguasai teknik evaluasi dan bertanggung jawab, 4) mampu berfikir secara sistematik dan 5) terdiri dari masyarakat belajar. ${ }^{2}$ Dari kriteria terbut tampak jelas bahwa guru profesional memiliki komitmen yang kuat dan menguasai meteri serta memiliki keterampilan dalam melaksanakan pembelajaran.

Merujuk pada Undang-undang guru dan dosen setidaknya guru profesional harus memiliki 4 kompetensi yang meliputi, 1) kompetensi pedagigik, 2) kompetensi profesional, 3) kompetensi sosial dan 4) kompetensi kepribadian. ${ }^{3}$ Rumusan ini memberi gambaran bahwa guru profesional harus mampu membuat perencanaan, pelaksanaan dan evaluasi pembelajaran serta pengembangan peserta didik untuk mengaktualisasikan berbagai potensi yang dimilikinya. Lebih jauh, ia harus mampu berkomunikasi dengan baik serta memiliki kepribadian yang mantab sehingga bisa menjadi contoh bagi peserta didiknya. Kompetensi tersebut merupakan syarat utama untuk menjadi guru profesional dalam implementasi kurikulum 2013.

Kurikulum 2013 adalah perubahan dalam upaya penyempurnaan dari kurikulum sebelumnya dan sebagai kelanjutan dari pengembangan kurikulum berbasis kompetensi yang telah dirintis pada tahun 2004. Kurikulum 2013 disusun dengan maksud untuk menyiapkan generasi yang siap dalam menghadapi tuntutan masa depan.

Sebagai wujud pengembangan dan penyempurnaan dari kurikulum sebelumnya, dalam Kurikulum 2013 terdapat perubahan pada 4 komponen yaitu pertama SKL; yang

${ }^{1}$ Mulyasa, E. Pengembangan dan Implementasi Kurikulum 2013, (Bandung: Rosda, 2013), 65.

2Iwan Wijaya, Menjadi Guru Profesional (Jawa Barat: CV Jejak, 2018), 16.

3Iwan Wijaya, Menjadi Guru Profesional (Jawa Barat: CV Jejak, 2018), 20. 
meliputi soft skills dan hards skills dengan mengasah 3 aspek, yaitu: sikap, pengetahuan, dan keterampilan. Kedua, standar isi; berkaitan dengan mata pelajaran diturunkan dari kompetensi. Ketiga, standar proses; yaitu proses pembelajaran dilakukan dengan pendekatan saintifik dan keempat, standar penilaian; dengan menggunakan penilaian autentik. $^{4}$

Guru Pendidikan agama Islam sebagai ujung tombak dalam proses belajar mengajar harus responsive dalam menghadapi perubahan yang terdapat dalam kurikulum 2013. Sebab baik tidaknya implementasi kurikulum 2013 tergantung pada kemampuan guru dalam menerjemahkannya dalam pembelajaran. Artinya, sebaik apapun konsep kurikulum tidak akanmemberikan dampak perubahan apapun jika guru sebagai implementator tidak memiliki kemampuan dan pemahaman yang memadai.

Hingga saat ini, implementasi kurikulum K13 di tingkat SMA dan SMK di Sidoarjo belum terlaksana secara maksimal dan menyeluruh. Hal ini terkendala karena penerapan kurikulum 2013 belum bisa sepenuhnya terpenuhi antara lain disebabkan karena kurangnya pemahaman dalam pelaksanaannya baik dalam perencanaan, pelaksa-naan dan penilaian.

Beberapa penelitian sebelumnya juga menggambarkan hal yang hampir serupa seperti terkendalanya kesiapan guru dalam melaksanakan atau mengembangkan pembelajaran ${ }^{5}$ dan penilaian sesuai tuntutan kurikulum 2013.6 Sebagaimana diuraikan sebelumnya bahwa proses pembelajaran dalam kurikulum 2013 menggunakan pendekatan saintifik belum bisa sepenuhnya dilaksanakan para guru termasuk guru Pendidikan agama Islam. Selain itu penilaian hasil belajar berbasis penilaian autentik yang dilakukan melalui berbagai cara yaitu fortofolio, produk, proyek, kinerja tertulis, penilaian diri dipandang guru sebagai suatu yang sangat memberatkan dan kurang bisa diaplikasikan dalam proses pembelajaran.

Dari latar belakang masalah diatas, maka artikel ini bertujuan untuk mendiskripsikan kesiapan guru Pendidikan agama islam dalam mengimplementasikan kurikulum 2013 di SMA 3 Sidoarjo dan SMK Antartika 1 sidoarjo.

\footnotetext{
4Imam Machali, Kebijakan Perubaban kurikulum 2013 dalam menyongsong Indonesia emas tabun 2045, Jurnal Pendidikan Islam::Volume IIII, Nomor 1, Juni 2014.

${ }^{5}$ Mardiana,S, Samiyatun, Implementasi Kurikulum 2013 dalam Pembelajaran Sejarah di SMA Negeri 1 Metro, Historia : Jurnal Pembelajaran Sejarah dan Kajian Sejarah Vol.5, No.1 Pebruari 2017, 45

${ }^{6}$ Mulabbiyah, Implementasi Kurikulum 2013 Pada Mata Pelajaran Pendidikan Agama Islam Berdasarkan Kma Nomor 165 Tahun 2014 Di Madrasah dalam jurnal Tatsqif: Jurnal Pemikiran dan Penelitian Pendidikan Volume 16, No. 2, Desember 2018, 108
} 


\section{Kesiapan Guru PAI dalam Mengimplementasikan Kurikulum 2013 di SMA 3 Sidoarjo dan SMK Antartika 1 Sidoarjo}

Adapun jenis penelitian ini adalah deskriptif kualitatif, dengan tujuan memahami fenomena yang dialami oleh subyek penelitian. Misalnya perilaku, persepsi, motivasi, tindakan, dan sebagainya, secara holistik dengan cara deskriptif dalam suatu konteks khusus yang alami tanpa ada campur tangan manusia dan dengan memanfaatkan secara optimal sebagai metode ilmiah yang lazim digunakan. ${ }^{7}$ Identifikasi variabel dalam penelitian ini merupakan jenis variabel tunggal, yaitu implementasi kurikulum 2013.

\section{B. Pembahasan}

\section{Kesiapan Guru PAI Dalam Mengimplementasi Kurikulum 2013 Ditinjau Dari Perencanaan Pembelajaran}

Rencana Pelaksanaan Pembelajaran atau yang dikenal dengan istilah RPP merupakan suatu bentuk perencanaan pembelajaran yang akan dilaksanakan oleh pendidik dalam kegiatan pembelajaran. ${ }^{8}$ Kemampuan merencanakan pembelajaran merupakan prasayarat utama yang harus dimiliki oleh setiap guru. Dalam Permendiknas Tentang Standar Kualifikasi Akademik dan Kompetensi Guru diuraikan bawa salah satu kualifikasi yang harus dimiliki oleh seorang guru adalah kompetensi pedagogis; yang mana secara tegas dikatakan bahwa salah satu tugas guru adalah merencanakan pembelajaran yang akan dilaksanakan. ${ }^{9}$ Berdasarkan hasil penelitian, diketahui bahwa guru PAI di SMAN 3 Sidoarjo telah menyusun rencana pelaksanaan pembelajaran (RPP) selama satu tahun sebelum pembelajaran belangsung.

Terdapat dua cara yang dilakukan guru PAI dalam menyusun RPP yaitu, mengkaji silabus, buku guru dan siswa. Telaah tersebut dilakukan dengan memperhatikan beberapa hal, seperti KI, KD, materi, alokasi waktu dan seterusnya. Hal ini sesuai dengan ketentuan Permendikbud Nomor 103 Tahun 2014 bahwa dalam mengkaji silabus meliputi $\mathrm{KI}, \mathrm{KD}$, materi pembelajaran, proses pembelajaran, penilaian pembelajaran, alokasi waktu, dan sumber belajar. ${ }^{10}$

Berdasarkan studi yang dilakukan peneliti terhadap dokumen RPP menunjukkan bahwa didalamnya terdapat beberapa komponen, diantaranya: satuan

${ }^{7}$ Umar Sidiq dan Moh. Miftachul Choiri, Metode Penelitian Kualitatif Di Bidang Pendidikan, (P Ponorogo: CV. Nata Karya, 2019), 5.

${ }^{8}$ Fadlillah, Implementasi Kurikulum 2013 Dalam Pembelajaran SD/MI, SMP/MTs, \& SMA/MA, (Yogyakarta: Ar-Ruzz Media, 2014), 144.

${ }^{9}$ Peraturan Menteri Pendidikan Nasional Republik Indonesia Nomor 16 Tahun 2007 Tentang Standar Kualifikasi Akademik dan Kompetensi Guru.

${ }^{10}$ Lampiran Permendibud Nomor 103 Tabun 2014 Pembelajaran pada Pendidikan Dasar dan Pendidikan Menengah, 9. 
pendidikan, peminatan/kempetensi, mata pelajaran, materi pokok, alokasi waktu, kompetensi inti, kompetensi dasar, indikator pencapaian kompetensi, tujuan pembelajaran, materi pembelajaran, metode pembelajaran, media, alat dan sumber pembelajaran, kegiatan pembelajaran, penilaian pembelajaran remedial dan pengayaan dan bahan dan sumber. ${ }^{11}$

Merujuk pada ketentuan diatas, tampak bahwa secara umum RPP yang dibuat guru PAI sudah sesuai dengan ketentuan yang ada. Meskipun demikian masih ditemukan bahwa guru PAI belum sepenuhnya mengikuti ketentuan yang ada. Hal ini terlihat masih adanya komponen tujuan serta pendekatan dan metode pembelajaran dalam RPP.

Berdasarkan hasil penelitian ditemukan bahwa dalam RPP guru PAI sudah mencantumkan pendekatan saintifik yang meliputi, mengamati, menanya, mencoba, mengasosiasi dan mengkomunikasikan. Dalam menjabarkan pendekatan saintifik, mereka berpedoman pada buku guru dan pengalaman dari workshop atau pelatihan yang telah mereka ikuti.

Berdasarkan hasil analisis RPP, sudah memuat instrumen penilaian pengetahuan, dan keterampilan dan sikap, serta dilengkapi dengan rubrik penilaian. Lampiran Permendikbud Nomor 103 Tahun 2014, menyebutkan bahwa pengembangan penilaian dalam RPP seharusnya dilakukan dengan cara menentukan lingkup, teknik, dan instrumen penilaian, serta membuat pedoman penskoran. ${ }^{12}$

Dari uraian di atas, dapat di simpulkan bahwa guru PAI di SMA Negeri 3 telah membuat rencana pelaksanaan pembelajaran (RPP) sesuai dengan ketententuan Permendikbud Nomor 103 Tahun 2013 sebagai implementasi Kurikulum 2013.

\section{Kesiapan Guru PAI Dalam Mengimplementasi Kurikulum 2013 Ditinjau Dari Pelaksanaan Pembelajaran}

Pelaksanaan pembelajaran merupakan implementasi dari rencana yang telah dituangkan dalam RPP. Seperti telah disebutkan sebelumnya, bahwa dalam RPP guru PAI telah merencanakan pembelajaran dengan pendekatan saintifik, yaitu mengamati, menanya, mencoba, mengasosiasi dan mengkomunikasikan.

Berdasarkan hasil penelitian, ditemukan bahwa aktifitas pembelajaran yang lakukan guru PAI terdiri dari tiga bagian, yaitu kegiatan pendahuluan, inti dan penutup. Kegiatan pendahuluan melakukan beberapa aktifitas pembelajaran diantaranya:

${ }^{11}$ Permendibud Republik Indonesia Nomor 103 Tahun 2014

${ }^{12}$ Lampiran permendikbud, Nomor 66 Tabun 2013 tentang Penilaian, 9. 


\section{Kesiapan Guru PAI dalam Mengimplementasikan Kurikulum 2013 di SMA 3 Sidoarjo dan SMK Antartika 1 Sidoarjo}

mengkondisikan suasana belajar yang menyenangkan; melakukan apersepsi; menyampaikan kompetensi dan cakupan materi dan menyampaikan lingkup dan teknik penilaian yang akan digunakan ${ }^{13}$.

Setelah kegiatan pendahuluan selesai, guru PAI melanjutkan langkah pembelajaran selanjutnya, yaitu kegiatan inti. Aktivitas pertama dalam kegiatan inti adalah mengamati, dilakukan dengan memanfaatkan fasilitas dan teknologi informasi yang ada. Pada langkah awal ini guru memutar video yang berkaitan dengan peristiwa hijrah Rasulullah SAW dari Makkah ke Madinah.

Mengutip dari Daryanto, bahwa mengamati sangat bermanfaat bagi pemenuhan rasa ingin tahu siswa, sehingga proses pembelajaran memiliki kebermaknaan yang tinggi. ${ }^{14}$ Sedangkan aktivitas mengamati dapat dilakukan melalui kegiatan membaca, mendengar, menyimak, melihat, menonton, dan sebagainya. ${ }^{15}$

Setelah proses mengamati selesai, selanjutnya mereka melakukan tanya jawab dengan meminta siswa bertanya atau mengomentari materi yang telah mereka amati. Jadi siswa tidak hanya sebatas melihat semata, namun siswa juga dilatih untuk memahami kegiatan/situasi apa yang sedang terjadi. proses menanya, telah dilaksanakan walaupun masih dibutuhkan stimulus dari guru untuk mengarahkan proses ini berjalan dengan lancar, guru perlu memberikan rangsangan supaya siswa bertanya setelah mengamati materi yang disuguhkan. Salah satu rangsangan yang dilakukan guru adalah memberikan nilai tambahan bagi siswa yang aktif.

Aktifits selanjutnya adalah mencoba/mengeksplorasi, dimana siswa diminta mencari, menemukan atau mendapatkan materi, yang dikenal dengan istilah discovery learning, merencanakan aktivitas belajar, melaksanakan proyek secara kolaboratif, dan pada akhirnya menghasilkan produk kerja yang dapat dipresentasikan kepada orang lain (project based learning), dan siswa untuk secara aktif menyelesaikan masalah dan membangun pengetahuannya (problem based learning).

13 Permendikbud Nomor 65 Tahun 2013 yang terdiri dari: Menyiapkan peserta didik secara psikis dan fisik untuk mengikuti proses pembelajaran; memberi motivasi belajar siswa secara kontekstual sesuai manfaat dan aplikasi materi ajar dalam kehidupan sehari-hari, dengan memberikan contoh dan perbandingan lokal, nasional dan internasional; mengajukan pertanyaan-pertanyaan yang mengaitkan pengetahuan sebelumnya dengan materi yang akan dipelajari; menjelaskan tujuan pembelajaran atau kompetensi dasar yang akan dicapai; dan menyampaikan cakupan materi dan penjelasan uraian kegiatan sesuai silabus

${ }^{14}$ Daryanto, Pendekatan Pembelajaran Saintifik Kurikulum 2013, (Yogyakarta: Gava Media, 2014). 60.

${ }^{15}$ Kemdikbud, Permendikbud No. 103 tahun 2014 tentang Pembelajaran Pada Pendidikan Dasar Dan Pendidikan Menengah (Jakarta: Kemdikbud, 2014), 5. 
Selama proses mengeksplorasi, terlihat juga proses mengasosiasi materi antar siswa dalam kelompok kelompok kecil maupun dalam kegiatan mengkomunikasikan berupa presentasi kelompok. Durasi yang ditentukan menyesuaikan kebutuhan kelompok dan kelas untuk menyelesaikan prosesnya. Langkah kegiatan inti yang terakhir yaitu mengkomunikasikan. Aktifitas mengkomunikasikan yang dilakukan oleh guru PAI tampak dengan memberikan kesempatan kepada siswa untuk mengemukakan hasil kajiannya tentang materi yang dikaji. Lalu siswa mengemukakan pendapatnya di depan kelas, dan kemudian dilakukan tanya jawab tentang perjuangan Rasulullah di Madinah. Secara bergantian masing-masing kelompok menyampaikan hasil diskusinya sedangkan kelompok yang lainnya memperhatikan/menyimak dan memberikan tanggapan.

Setelah kegiatan inti selesai,dilakukan kegiatan penutup. dengan memberikan kesempatan pada masing-masing kelompok untuk menyampaikan kesimpulan menurut mereka masing-masing. Akhirnya, Ia memberi penguatan atas kesimpulan materi yang telah dipelajari. Di akhir pembelajaran, untuk mengetahui keberhasilan dan ketuntasan belajar siswa, maka juga dilakukan penilaian. Kegiatan ini dilakukan dengan meminta siswa untuk mengerjakan soal yang telah dipersiapkan sebelumnya.

Dari uraian di atas, maka kegiatan inti yang dilakukan guru PAI terdapat kesesuaian dengan Permendibud Nomor 103 Tahun 2014 Pembelajaran pada Pendidikan Dasar dan Pendidikan Menengah dan Permendikbud nomor 65 tahun 2013 tentang standar proses yang merupakan acuan dalam mengimplementasikan Kurikulum 2013.

\section{Kesiapan Guru PAI Dalam Mengimplementasi Kurikulum 2013 Ditinjau Dari} Pelaksanaan Penilaian

Sesuai ketentuan yang tertera dalam Permendikbud No 66 tahun 2013 tentang standar penilaian, menyebutkan bahwa penilaian otentik merupakan penilaian yang dilakukan secara komprehensif untuk menilai mulai dari masukan (input), proses, dan keluaran (output) pembelajaran. Penilaian tersebut meliputi penilaian sikap, pengetahuan dan ketrampilan. ${ }^{16}$

Implementasi penilaian otentik yang dilakukan oleh guru PAI terlihat dari aktifitas guru dalam melakukan penilaian sikap, pengetahuan dan keterampilan. Berdasarkan pengamatan yang dilakukan peneliti, diketahui bahwa guru PAI dalam

16Salinan Lampiran Permendikbud No 66 Tahun 2013 Tentang Standar Penilaian, 4. 


\section{Kesiapan Guru PAI dalam Mengimplementasikan Kurikulum 2013 di SMA 3 Sidoarjo dan SMK Antartika 1 Sidoarjo}

menilai sikap siswa menggunakan beberapa teknik penilaian, diantaranya adalah observasi, penilaian diri, penilaian antar sesama dan penilaian jurnal.

Observasi tampak digunakan untuk menilai perilaku siswa ketika proses pembelajaran, seperti mengamati, diskusi dan presentasi. Dengan kata lain, seluruh kegiatan siswa selama proses pembelajaran tidak luput dari pengamata guru. kegiatan ini dilakukan guru dengan menggunakan pedoman observasi yang berisi sejumlah indikator perilaku yang diamati. Selain observasi, juga digunakan penilaian diri, penilaian antar sesama siswa dan jurnal. ${ }^{17}$ Dengan demikian, kegiatan penilaian sikap yang dilakukan guru PAI sesuai dengan kreteria penilaian otentik sebagaimana dianjurkan dalam kurikulum 2013.

Selanjutnya adalah penilaian pengetahuan. Berdasarkan hasil penelitian diketahui bahwa penilaian pengetahuan yang dilakukan guru PAI menggunakan tiga teknik penilaian. diantaranya, tes tulis, tes lisan dan penugasan. tes tulis dilakukan dengan meminta siswa mengerjakan soal-soal yang ada di buku paket. Sedangkan tes lisan dilakukan dengan memberi pertanyaan secara langsung kepada siswa utnuk dijawab dengan lisan. Sedangangkan penilaian penugasan dilakukan dengan cara memberi tugas-tugas tertentu kepada siswa.

Dalam Permendikbud Nomor 66 Tahun 2013 tentang penilian pendidikan diuraikan: Pendidik menilai kompetensi pengetahuan melalui tes tulis, tes lisan, dan penugasan. 1) Instrumen tes tulis berupa soal pilihan ganda, isian, jawaban singkat, benar-salah, menjodohkan, dan uraian. Instrumen uraian dilengkapi pedoman penskoran. 2) Instrumen tes lisan berupa daftar pertanyaan. 3) Instrumen penugasan berupa pekerjaan rumah atau projek yang dikerjakan secara individu atau kelompok sesuai dengan karakteristik tugas.

Merujuk pada pedoman di atas, dalam penilaian pengetahuan selain tes tulis, tes lisan dan penugasan. Dengan demikian, maka kegiatan penilaian pengetahuan yang dilakukan menunjukkan kesesuaian dengan ketentuan yang ada. Terakhir adalah penilaian keterampilan. Adapun teknik penilaian keterampilan secara tegas diuraikan dalam Permendikbud Nomor 66 Tahun 2013 tentang penilian pendidikan bahwa:

\footnotetext{
${ }^{17}$ Berkaitan dengan teknik penilaian secara tegas diuraikan dalam Permendikbud Nomor 66 Tahun 2013 tentang penilian pendidikan di uraikan bahwa: Pendidik melakukan penilaian kompetensi sikap melalui observasi, penilaian diri, penilaian "teman sejawat"(peer evaluation) oleh peserta didik dan jurnal. Instrumen yang digunakan untuk observasi, penilaian diri, dan penilaian antar peserta didik adalah daftar cek atau skala penilaian (rating scale) yang disertai rubrik, sedangkan pada jurnal berupa catatan pendidik. Permendikbud Nomor 66 Tahun 2013 tentang penilian pendidikan, 5.
} 
Pendidik menilai kompetensi keterampilan melalui penilaian kinerja, yaitu penilaian yang menuntut peserta didik mendemonstrasikan suatu kompetensi tertentu dengan menggunakan tes praktik, projek, dan penilaian portofolio. Instrumen yang digunakan berupa daftar cek atau skala penilaian (rating scale) yang dilengkapi rubrik. 1) Tes praktik adalah penilaian yang menuntut respon berupa keterampilan melakukan suatu aktivitas atau perilaku sesuai dengan tuntutan kompetensi. 2) Projek adalah tugas-tugas belajar (learning tasks) yang meliputi kegiatan perancangan, pelaksanaan, dan pelaporan secara tertulis maupun lisan dalam waktu tertentu.3) Penilaian portofolio adalah penilaian yang dilakukan dengan cara menilai kumpulan seluruh karya peserta didik dalam bidang tertentu yang bersifat reflektif-integratif untuk mengetahui minat, perkembangan, prestasi, dan atau kreativitas peserta didik dalam kurun waktu tertentu. Karya tersebut dapat berbentuk tindakan nyata yang mencerminkan kepedulian peserta didik terhadap lingkungannya.

Berdasarkan hasil penelitian, diketahui bahwa dalam penilaian keterampilan mereka menggunakan penilaian kinerja dan portofolio. Penilaian kinerja tampak dilakukan Penilaian kinerja tampak digunakan guru dengan cara memberikan tugas kepada siswa secara berkelompok untuk mempragakan perjalanan hijrah nabi dari Makkah ke Madinah. Pada kesempatan yang lain, penilaian kinerja juga tampak digunakannya pada materi yang berbeda yaitu memperhatikan keterampilan siswa dalam memperaktekkan memandikan jenazah.

Sedangkan guru yang lain, dalam menilai keterampilan lebih cenderung menggunakan penilaian portofolio. dengan cara melihat hasil atau bukti pekerjaan siswa dalam kurun waktu tertentu sehingga akan diketahui siswa yang terampil dengan yang tidak. Sedangkan materi pelajaran tertentu, mereka juga menggunakan penilaian produk. Seperti materi Muamalah, mereka diberi tugas untuk melakukan observasi praktek muamalah di bank-bank terkait, kemudian hasinya dilaporkan dalam bentuk makalah.

\section{Kesimpulan}

Terkait dengan kesiapan guru PAI dalam mengimplementasikan kurikulum 2013 di SMA Negeri 3 dan SMK Antartika 1 Sidoarjo telah memiliki kesiapan yang baik. Hal tersebut dapat dilihat dari pembuatan perencanaan, pelaksanaan dan evaluasi pembelajaran yang dilakukan sesuai dengan kegiatan pembelajaran sesuai Pendekatan Santifik. Kegiatan perencanaan pembelajaran dilakukan guru PAI dengan mengkaji silabus, mengkaji buku guru, menyusun RPP serta menjabarkan langkah kegiatan Pendekatan Saintifik. Namun, sebagian 


\section{Kesiapan Guru PAI dalam Mengimplementasikan Kurikulum 2013 di SMA 3 Sidoarjo dan SMK Antartika 1 Sidoarjo}

guru PAI di dalam RPP belum menjabarkan dengan teknik dan instrument penilaian yang akan digunakan. Dalam pelaksanaan pembelajaran, Guru PAI telah melaksanaan pembelajaran menggunakan Pendekatan Saintifik yang meliputi kegiatan mengamati, menanya, mengumpulkan informasi/ mencoba, mengasosiasi atau menalar, dan mengkomunikasikan (5M). Namun pelaksanaan kegiatan 5M tersebut belum maksimal, karena kurangnya pemahaman sebagian guru tentang pendekatan saintifik. Sedangkan dalam penilaian Guru PAI sudah menggunakan penilaian otentik untuk menilai kompetensi sikap pengetahuan dan keterampilan Peserta didik.

\section{Daftara Rujukan}

Mulyasa, E. Pengembangan dan Implementasi Kurikulum 2013. Bandung: Rosda, 2013.

Iwan Wijaya. Menjadi Guru Profesional. Jawa Barat: CV Jejak, 2018.

Machali, Imam. "Kebijakan Perubahan kurikulum 2013 dalam menyongsong Indonesia emas tahun 2045”, Jurnal Pendidikan Islam, Volume IIII, Nomor 1, Juni 2014.

Mardiana, S. Samiyatun. "Implementasi Kurikulum 2013 dalam Pembelajaran Sejarah di SMA Negeri 1 Metro”, Historia: Jurnal Pembelajaran Sejarah dan Kajian Sejarah Vol.5, No.1, 2017.

ulabbiyah, "Implementasi Kurikulum 2013 Pada Mata Pelajaran Pendidikan Agama Islam Berdasarkan Kma Nomor 165 Tabun 2014 Di Madrasab”, Jurnal Tatsqif: Jurnal Pemikiran dan Penelitian Pendidikan Vol 16, No. 2, 2018.

Sidiq, Umar. dan Choiri, Moh. Miftachul. Metode Penelitian Kualitatif Di Bidang Pendidikan. P Ponorogo: CV. Nata Karya, 2019.

Fadlillah. Implementasi Kurikulum 2013 Dalam Pembelajaran SD/MI, SMP/MTs, \& SMA/MA. Yogyakarta: Ar-Ruzz Media, 2014.

Daryanto. Pendekatan Pembelajaran Saintifik Kurikulum 2013, (Yogyakarta: Gava Media, 2014. 